\title{
AUTHOR INDEX Volume 19
}

Abed El Al, S., see Shehadeh, A. M.

19 (2016) 1650005

Acharya, K., see Pandey, V.

19 (2016) 1672001

Albtoush, O. M., see Shehadeh, A. M.

19 (2016) 1650005

Annear, P. T., see Falconer, T. M.

19 (2016) 1650004

Azarang, A., see Roshanzamir, S.

Barrio-Alonso, M., see Juan-García, F. J.

19 (2016) 1650020

19 (2016) 1650006

Bessho, K., see Mishima, S.

Bigham-Sadegh, A., see Oryan, A.

19 (2016) 1672003

19 (2016) 1650003

Breidahl, W. H., see Falconer, T. M.

Chatterjee, R., Malliaropoulos, N. and Padhiar, N., Diagnosis and Management of Plantar Plate Tear in an Elite $400 \mathrm{M}$ Hurdler

19 (2016) 1650004

19 (2016) 1672002

19 (2016) 1650007

19 (2016) 1650011

19 (2016) 1650020

19 (2016) 1650013

19 (2016) 1650014

19 (2016) 1672001

19 (2016) 1650019

Evans, P. J., see Marquardt, T. L.

Falconer, T. M., Gohil, S., Tusak, L., Breidahl, W. H. and Annear, P. T., Tunnel

Positioning in Remnant Sparing Double Bundle ACL Reconstruction - A 2-Year

Study of MRI Tunnel Positions, Clinical Outcomes and Tunnel Confluence

19 (2016) 1650004

Formigo-Couceiro, J., see Juan-García, F. J.

Gabra, J. N., see Marquardt, T. L.

Gale, N. C., Kuxhaus, L. and Ciani, M. J., Erector Spinae Muscle - Iliocostalis Anatomic Variation

Gohil, S., see Falconer, T. M.

19 (2016) 1650006

19 (2016) 1650019

19 (2016) 1650007

19 (2016) 1650004

19 (2016) 1672001

Hafiz, N., see Pandey, V.

Hori, M., see Mishima, S.

Horiuchi, T., see Kanno, Y.

19 (2016) 1672003

19 (2016) 1650012

Ichikawa, K., see Mamoto, K.

19 (2016) 1650015

Imai, Y., see Mamoto, K.

19 (2016) 1650015

Ja'far, A., see Shehadeh, A. M.

19 (2016) 1650005

Juan-García, F. J., Formigo-Couceiro, J., Barrio-Alonso, M. and Ouviña-Arribas, R., Effectiveness of Botulinum Toxin Type A in Carpal Tunnel Syndrome

19 (2016) 1650006 
Kanno, Y., Toda, H., Horiuchi, T., Nagai, K. and Katayose, M., Reliability and Validity Study of a Measurement Method for the Glenoid Version by a 3-Dimensional Bone Model from 3.0 Tesla MRI

Karsten, K. and Martin, E., Impact of Cartilage Damage on Arthrogenic Muscle Inhibition in Patients with Meniscus Injuries

Katayose, M., see Kanno, Y.

Kim, D.-H., see Moon, M.-S.

Kim, D.-H., see Moon, M.-S.

Kim, D. H., see Moon, M.-S.

Kim, D.-H., see Moon, M.-S.

Kim, D.-H., see Moon, M.-S.

Kim, D.-H., see Moon, M.-S.

Kim, S.-J., see Moon, M.-S.

Kim, S.-J., see Moon, M.-S.

Kim, S.-S., see Moon, M.-S.

Kim, S.-S., see Moon, M.-S.

Kim, S.-S., see Moon, M.-S.

Komatani, T., see Mishima, S.

Kuxhaus, L., see Gale, N. C.

Lee, S.-Y., see Moon, M.-S.

Lee, S.-Y., see Moon, M.-S.

Li, Z.-M., see Marquardt, T. L.

Malliaropoulos, N., see Chatterjee, R.

Mamoto, K., Ohta, Y., Ichikawa, K., Imai, Y., Minoda, Y., Takaoka, K. and Nakamura, H., Co-Administration of Systemic Zoledronate Promotes Osteogenesis Induced by a Local Co-Delivery of Recombinant Human Bone Morphogenetic Protein-2 and $\beta$-Tricalcium Phosphate in the Bone Marrow of the Rabbit Femur

Maor, D., Xu, J., Mudhar, K. S. and Yates, P. J., A Modern Constrained Acetabular Component for the Management of Hip Instability

Marquardt, T. L., Gabra, J. N., Evans, P. J., Seitz, W. H. and Li, Z.-M., Thickness and Stiffness Adaptations of the Transverse Carpal Ligament Associated with Carpal Tunnel Syndrome

Martin, E., see Karsten, K.

Michalea-Dimoulea, E., Papailias, T. and Damigos, D., Low Back Pain: Positive Correlation of Low Socioeconomic Status and Pain Intensity. A Cross-Sectional Study

Minoda, Y., see Mamoto, K.

Mishima, S., Takahashi, K., Hori, M., Komatani, T., Yamada, J. and Bessho, K., Perioperative Management of Mandibular Fractures in a Patient with Severe Hyperthyroidism: A Case Report

Monazzah, S., see Oryan, A.

Moon, M.-S., Kim, D.-H., Kim, S.-J. and Yoon, M.-G., Neurological Outcome in Association with Column Restoration and Consolidation of Unstable Thoracic and Lumbar Spine Fractures - Assessment by Clinical Examination and Image Studies

Moon, M.-S., Kim, D. H., Kim, S.-J., Yoon, M.-G., Kim, S.-S. and Sihn, J.-C., Anterior Lumbar Interbody Fusion with Hartshill Horseshoe Cage
19 (2016) 1650012

19 (2016) 1650001
$\mathbf{1 9}(2016) 1650012$
$\mathbf{1 9}(2016) 1650008$
$\mathbf{1 9}(2016) 1650009$
$\mathbf{1 9}(2016) 1650010$
$\mathbf{1 9}(2016) 1650016$
$\mathbf{1 9}(2016) 1650017$
$\mathbf{1 9}(2016) 1650018$
$\mathbf{1 9}(2016) 1650008$
$\mathbf{1 9}(2016) 1650010$
$\mathbf{1 9}(2016) 1650009$
$\mathbf{1 9}(2016) 1650010$
$\mathbf{1 9}(2016) 1650016$
$\mathbf{1 9}(2016) 1672003$
$\mathbf{1 9}$ (2016) 1650007
$\mathbf{1 9}(2016) 1650017$
$\mathbf{1 9}$ (2016) 1650018
$\mathbf{1 9}$ (2016) 1650019
$\mathbf{1 9}$ (2016) 1672002

19 (2016) 1650015

19 (2016) 1650002

19 (2016) 1650019

19 (2016) 1650001

19 (2016) 1650013

19 (2016) 1650015

19 (2016) 1672003

19 (2016) 1650003

19 (2016) 1650008

19 (2016) 1650010 
Moon, M.-S., Lee, S.-Y., Kim, D.-H. and Yoon, M.-G., Healing Pattern of the Interlocking Intramedullary Nailed Closed Tibial Shaft Fractures - Effect of Age, Im Nail and Fibula on Callus Formation

Moon, M.-S., Kim, D.-H., Yoon, M.-G., Kim, S.-S. and Sihn, J.-C., Facet Geometry and Unilateral Lumbar Disc Herniation

Moon, M.-S., Kim, D.-H., Yoon, M.-G., Kim, S.-S. and Sihn, J.-C., Radiological Assessment of Bony Union After Occipitocervical Fusion

Moon, M.-S., Kim, D.-H., Yoon, M.-G. and Lee, S.-Y., Healing Pattern of Interlocked Intramedullary Nailed Humeral Shaft Fracture

Mudhar, K. S., see Maor, D.

Nagai, K., see Kanno, Y.

Nakamura, H., see Mamoto, K.

Neelapala, Y. V. R., Reddy, Y. R. S. and Danait, R., Effect of Mulligan's Posterolateral Glide on Shoulder Rotator Strength, Scapular Upward Rotation in Shoulder Pain Subjects - A Randomized Controlled Trial

Ohta, Y., see Mamoto, K.

Oryan, A., Bigham-Sadegh, A. and Monazzah, S., The Effect of hPRP and Autograft-PRP on Bone Healing in the Radial Defect of Rat

Ouviña-Arribas, R., see Juan-García, F. J.

Padhiar, N., see Chatterjee, R.

Pandey, V., Vijayan, S., Hafiz, N., Deepika, N. and Acharya, K., Does Congenital Absence of the Long Head of Biceps Tendon Render Shoulder Unstable Leading to Bony Bankart and Posterior Labral Tear: A Case Report and Review of the Literature

Papailias, T., see Michalea-Dimoulea, E.

Pommering, T. L., see Young, J. A.

Reddy, Y. R. S., see Neelapala, Y. V. R.

Roshanzamir, S., Azarang, A. and Dabbaghmanesh, A., Rational for Hypothyroidism Screening in Carpal Tunnel Syndrome Patients Without Definite Predisposing Factor

Salem, A., see Shehadeh, A. M.

Seitz, W. H., see Marquardt, T. L.

Shahin, I. A., see Shehadeh, A. M.

Shehadeh, A. M., Abed El Al, S., Ja'far, A., Salem, A., Shahin, I. A. and Albtoush, O. M., A Modified Decompression and Bone Graft Technique for the Treatment of Avascular Necrosis of the Femoral Head

Sihn, J.-C., see Moon, M.-S.

Sihn, J.-C., see Moon, M.-S.

Sihn, J.-C., see Moon, M.-S.

Takahashi, K., see Mishima, S.

Takaoka, K., see Mamoto, K.

Toda, H., see Kanno, Y.

Tusak, L., see Falconer, T. M.

Vijayan, S., see Pandey, V.

Xu, J., see Maor, D.

Yamada, J., see Mishima, S.

Yang, J., see Young, J. A.

Yates, P. J., see Maor, D.

Yoon, M.-G., see Moon, M.-S.
19 (2016) 1650017

19 (2016) 1650016

19 (2016) 1650009

19 (2016) 1650018

19 (2016) 1650002

19 (2016) 1650012

19 (2016) 1650015

19 (2016) 1650014

19 (2016) 1650015

19 (2016) 1650003

19 (2016) 1650006

19 (2016) 1672002

19 (2016) 1672001

19 (2016) 1650013

19 (2016) 1650011

19 (2016) 1650014

19 (2016) 1650020

19 (2016) 1650005

19 (2016) 1650019

19 (2016) 1650005

19 (2016) 1650005

19 (2016) 1650009

19 (2016) 1650010

19 (2016) 1650016

19 (2016) 1672003

19 (2016) 1650015

19 (2016) 1650012

19 (2016) 1650004

19 (2016) 1672001

19 (2016) 1650002

19 (2016) 1672003

19 (2016) 1650011

19 (2016) 1650002

19 (2016) 1650008 
Yoon, M.-G., see Moon, M.-S.

19 (2016) 1650009

Yoon, M.-G., see Moon, M.-S.

19 (2016) 1650010

Yoon, M.-G., see Moon, M.-S.

19 (2016) 1650016

Yoon, M.-G., see Moon, M.-S.

19 (2016) 1650017

Yoon, M.-G., see Moon, M.-S.

19 (2016) 1650018

Young, J. A., Cuff, S. C., Yang, J. and Pommering, T. L., Comparison of Spinal and Pelvic Posture and Muscle Flexibility in Those with Spondolytic and Non-Spondolytic Low Back Pain

19 (2016) 1650011 